\title{
LEGAL CONDITIONS FOR EMPLOYMENT OF FoREIGNERS IN POLAND IN THEORY AND PRACTICE
}

\section{Ivanna Kyliushyk*}

\begin{abstract}
The article discusses the problems faced by employers and foreigners in the procedures for obtaining work permits. Among others, there is a lack of information for employers, a lack of information in languages understood by foreigners, an insufficient offer of free consultations, non-transparent procedures, long queues, extended deadlines for processing applications. The article based on an analysis of law, the author's observations and research report data.
\end{abstract}

Keywords: Economic migrations, employment of foreigners, foreigners from third countries, Polish labor market

Creating the English-language version of the journal "Zoon Politikon" is financed under contract No. 724/P-DUN/2018 from the funds allocated by the Minister of Science and Higher Education for dissemination of science.

"Ivanna Kyliushyk, M.A., University of Warsaw, Warsaw, Poland

E-mail: ivannakyl@gmail.com | ORCID: https://orcid.org/0000-0001-5347-649X 
Introduction

This article discusses legal issues, theoretical and practical, concerning the employment of foreigners from third countries.

The demand for foreign labor in Poland and law concerning their employment have recently becomea popular topic, both in the scientific community and among the representatives of state authorities. The phenomenon of the inflow of economic migrants and the resulting interest of the market seem to be an extremely interesting research topic (Piotrowski, Oraniściak-Krzykowska 2014, p. 261).

It is difficult to estimate the total number of foreigners staying in Poland, which is related, among others, to undocumented/ unregistered immigration. Therefore, no reliable source of data exists that would allow for tracing the scale of theimmigration. Traditionally, scientists and experts base their research on administrative and statistical data sources, usually on residence permit data issued by the Office for Foreigners, work permits data and employers' declarations on entrusting work to foreigners from the Ministry of Family, Labor and Social Policy, data on foreigners registered for permanent or temporary residence (PESEL register) from the Ministry of Digital Affairs, data on natural persons - foreigners from the Central Register of Entities - the National Register of Taxpayers (CRP KEP), data on insured foreigners and their family members from the Polish Social Insurance Institution (ZUS) and its Central Register. It is worth noting that none of these sources provides reliable and comprehensive data.

As of 7 August 2019, according to the data of the Office for Foreigners, 407995 foreigners held a valid residence permit on the territory of Poland, the largest groups thereof being citizens of Ukraine, Belarus, Germany, Russia, Vietnam, India, China (Urząd do Spraw Cudzoziemców 2019). The data of the Office for Foreigners does not include non- 
registered EU citizens and those foreigners staying in Poland on the basis of visas and visa-free travel.

According to the data of the Labor Market Department of the Ministry of Family, Labor and Social Policy the number of work permits issued to foreigners has been increasing since 2015. In 2015, 65786 work permits were issued, and in 2016 - 127 394, which was an increase of approx. 94\% compared to 2015. In 2017, 235626 permits were issued, which represented an increase of 85\% compared to 2016. In 2018, 328 768 permits were issued, which represented $28.33 \%$ increase compared to 2017. In the first half of 2019, 217297 work permits for foreigners were issued (MRPiPS (n.d.).

Due to the existence of a large group of foreigners working in Poland, it is necessary to look at the legal conditions of their employment and the problems faced by employers and foreigners during the legalization procedures.

As foreign EU citizens are not obliged to possess a work permit when undertaking employment in another EU Member State, the current analysis is limited only to the group of foreigners from non-EU.

For the sake of clarity, it should be noted that any person who is not a Polish citizen is recognized as a foreigner (Ustawa o cudzoziemcach 2013, art. 3 point 2). Every person which is not a citizen of a country belonging to the European Union, the European Economic Area or Switzerland is considered a non-EU national-foreigner.

The aim of this paper is to explain the issues faced by employers and foreigners in matters of legal employment.

The main thesis of the article states that due to the recurrence of the issues related to obtaining work permits, the law on employment of foreigners needs to be amended.

The study was based on a legal analysis, analysis of statistical data and subject literature, as well as on several years of the author's experience as an advisor at the Consultation Office for Foreigners. The study 
also analyses the report from the "Male and female employers and the issue of employment of male and female foreigners" study.

The first part of the article presents the legal framework determining the rules of entrusting work to foreigners in Poland. In the next section of the study, statistical data concerning issued documents legalizing the employment of foreigners in 2018 is analyzed. The following section presents the problems resulting from the employment of foreigners. The paper ends with a summary and an attempt to indicate the most crucial guidelines for the Polish migration policy.

This article is addressed to all those interested in the issue of legal employment conditions of foreigners from third countries in Poland. The study results may be utilized by students and scientists in conducting their own research, and by the Polish government in planning the migration policy.

Legal conditions of employment of non-EU national foreigners in theory

"One of the basic objectives of the Polish immigration policy is to supplement the existing labor shortages with immigrants interested in working in Poland" (Piotrowski, Oraniściak-Krzykowska 2016, p. 315).

Among other EU countries, Poland has the most liberal access to the labor market for non-EU national foreigners. This is due to the fact that Poland, like other EU countries, is plagued by significant demographic issues caused by an ageing population, a general increase in life expectancy and the fact that after Poland's accession to the EU and the Schengen area, a significant proportion of working Poles has emigrated.

According to the forecasts of the Central Statistical Office (GUS), in 2035 every fourth citizen of Poland (about 27\%) will be retired. The Government Population Council, as well as numerous employers' associations (e.g. the Union of Entrepreneurs and Employers, Employers of Poland, Polish Confederation Lewiatan) state that one of the ways 
of coping with the demographic crisis and its effects on the labor and financial markets and social insurance is to open the Polish labor market to immigrants from non-EU countries (Wieńska-Di Carlo, Klaus 2018, p. 1).

Poland, unlike the more developed EU states, is not able to attract economic migrants from other, economically disadvantaged EU countries, because earning prospects in Poland are not as attractive. For this reason, Poland attracts foreigners from non-EU countries: mainly from the Eastern Partnership countries and Russia due to their linguistic and cultural similarity, which contributes to faster integration.

To understand the conditions of employing non-EU foreigners in Poland, it is necessary to examine the applicable provisions of law.

The most important acts regulating labor laws concerning foreigners in Poland are: Act on employment promotion and labor market institutions of 20 April 2004 (Ustawa o promocji zatrudnienia i instytucjach rynku pracy 2004); Ordinance of the Minister of Labor and Social Policy of 29 J anuary 2009 on issuing work permits for foreigners (MPIPS 2009a); Regulation of the Minister of Labor and Social Policy of 29 J anuary 2009 regarding defining circumstances in which a work permit is issued to a foreigner regardless of detailed terms defined for the issuance of a work permit to a foreigner (MPiPS 2009b); Regulation of the Minister of Labor and Social Policy of 21 April 2015 on the cases when entrusting work to a foreigner within the Republic of Poland is allowed without the necessity to obtain a work permit (MPiPS 2015); Regulation of the Minister of Family, Labor and Social Policy of 7 September 2018 amending the regulation on subclasses of activity according to the Polish Classification of Activity (PKD) according to which seasonal work permits for foreigners are issued (MPRiPS 2019).

The provisions of the law categorize non-EU foreigners in relation to labor market access provisions. There are foreigners who are free to access the labor market, foreigners authorized to take up employment on 
the basis of a declaration on entrusting work to a foreigner and foreigners authorized to takeup employment in Poland on the basis of a work permit.

"Entrusting work to foreigners on the Polish labor market is strongly regulated by the current provisions of law, which results in a clearly visible tendency to categorize foreigners together with a simultaneous differentiation of the rules of access to the labor market for the particular categories" (Piotrowski, Oraniściak-Krzykowska 2014, p. 262).

The Ordinance of 21 April 2015 specifies the cases in which the entrusting of work to a foreigner within the territory of the Republic of Poland is permissible without the need to obtain a work permit, and art. 87 point 2 of the Act on employment promotion and labor market institutions specifies the group of foreigners exempt from that obligation. They constitute a relatively large group of foreigners who are free to access the Polish labor market (MPiPR 2015; Ustawa o promocji zatrudnienia i instytucjach rynku pracy 2004, art. 87 point 2).

In the next part of the article the legal basis for employing foreigners shall be considered: the declaration on entrusting work to a foreigner, the seasonal work permit and the work permit.

Only citizens from the Eastern Partnership member states (with the exception of Azerbaijan), namely Ukraine, Belarus, Moldova, Georgia, Armenia and Russia may take up employment in Poland on the basis of a declaration on entrusting work to a foreigner.

The declarations are issued by district (poviat) labor offices pursuant to art. 88z-88z of the act on employment promotion and labor market institutions (Ustawa o promocji zatrudnienia i instytucjach rynku pracy 2004, art. 88z-88za). The declaration entitles a foreigner to perform work for up to 6 months within a period of 12 months. This is a simplified process of employing foreigners from the aforementioned countries concerning the performance of non-seasonal work. 
The declaration on entrusting work to a foreigner is submitted by the employer to the district (poviat) labor office, which enters the declaration into the register of declarations. From 2018 onwards, in order to improve and shorten the processing and waiting time for entry, declarations are managed via the praca.gov.pl portal.

The employer is obliged to inform the competent district (poviat) labor office about taking up employment by a foreigner no later than on the day of the employment's commencement, or about not taking up employment by a foreigner within 7 days from the employment's commencement date specified in the register of declarations. Non-compliance with the obligation to provide information on taking up or not taking up employment by a foreigner is subject to a fine.

If the foreigner was employed on the basis of a declaration and an employment contract and the employer plans to continue the employment of the foreigner for a longer period of time, the employer may, after 3 months of performing work by the foreigner, apply for a simplified work permit to the competent voivode (province governor). A foreigner may also apply for a residence and work permit on their own. If a permit application is completed and the foreigner receives a passport stamp confirming its submission, the foreigner's work will be considered legal until the decision is made (Ustawa o promocji zatrudnienia i instytucjach rynku pracy 2004, art. 88za).

In 2018, seasonal work permits were introduced in Poland, which can be obtained by all non-EU foreigners for a period no longer than 9 months in a calendar year.

The seasonal work permit is issued by district (poviat) labor offices pursuant to art. 88n-88y of the act on employment promotion and labor market institutions (Ustawa o promocji zatrudnienia i instytucjach rynku pracy 2004, art. 88n-88y). 
The permit is issued for foreigners performing seasonal work directly related to agriculture, forestry, hunting and fishing or accommodation and catering (MRPiPS 2018). During the permit's validity period, it is possible for a foreigner to perform all seasonal work, not only the one indicated in the permit, and to perform work other than seasonal work for a maximum of 30 days.

The permit for seasonal work is issued by the Poviat Starost (district governor) competent for the seat or place of residence of the entity entrusting work to a foreigner at the request of the employer submitted via the praca.gov.pl portal.

A work permit is issued by voivodeship offices on the basis of footnotes included in art. 88-88m of the act on employment promotion and labor market institutions and in the Regulation on the issuance of work permits for foreigners (Ustawa o promocji zatrudnienia i instytucjach rynku pracy 2004, art. 88-88m; MPiPS 2009a; MPiPS 2009b).

A work permit is a document which entitles a foreigner to take up legal employment in Poland. The permit is issued for a definite period of time, not longer than 3 years and may be renewed. It is extended via a written request of the entity entrusting the performance of work to a foreigner, submitted not earlier than within 90 days and not later than within 30 days before the expiry of the permit's validity period.

Work permits are issued by the voivode (province governor) upon the employer's request. In order to obtain a work permit, it is necessary, among other things, to submit a document called "Starost's Information" competent for the primary place of employment of a foreigner or the place of registration of an entity entrusting work on the impossibility of satisfying the human resources needs of an entity entrusting work to a foreigner on the basis of registers of the unemployed and job seeking or on the basis of a negative result of recruitment organized for the employer. 
The applying employer must, during the commitment procedure, take measures that consider local labor market condition. The employer is obliged to search for employees for the position which is the subject of the application, from among Polish citizens as well as persons for whom the permit is not required first (Piekutowska 2007, p. 207).

In some cases, the employer may apply for a work permit without the need to obtain prior information from the Starost.

After being authorized (in any way), the employer transfers the authorization to the foreigner. On its basis, the foreigner may apply for a residence permit allowing them to take up employment in Poland: a visa or a temporary residence permit, allowing for a stay in the visa-free regime for up to 90 days within the next 180 days ${ }^{1}$. The employer is obliged to enter into a written agreement with the foreigner, providing them with a translated copy in a language they can understand beforehand. The employer is obliged to include the conditions of the permit in the agreement.

Consequently, the Polish labor market can be accessed by non-EU foreigners in various ways. It is worth noting, however, that all types of permits are issued for a specific foreigner to work for a specific employer under specific conditions: type of contract, position and obligations, working time, remuneration. If a foreigner wants to change their employer, then the new employer must obtain a new permit for the employee. When calculating the periods of employment on the basis of a declaration, the periods for which the declaration was registered are considered. In total, the period of employment of a foreigner may not exceed 6 months on the basis of a declaration and 9 months on the basis of a seasonal work permit within the following 12 months, regardless of the number of employers entrusting work.

' Polish law allows foreigners who are residing in accordance with the visa-free regime to take up employment, which proves how liberal the access to the labor market is. 
Number of economic migrants in Poland

According to the data from the Male and female employers and the issue of employment of male and female foreigners study, an increasing number of businesses employ male and female workers from outside the European Union. Among the surveyed businesses, as many as 39\% employed such persons at the time of the study. In the medium-sized enterprises sector, this percentage was as high as 65\%, and in the sector of small enterprises - 48\%. The lowest percentage is in the micro-enterprises sector - only $4 \%$ of the respondents indicated that they employ people from outside the EU. The businesses with the highest percentage of employed foreigners operate in the construction and industrial sectors - 53\% of small and medium-sized companies operate in the construction sector and $49 \%$ of small and medium-sized companies in the industrial sector. Only 35\% of small and medium sized service sector enterprises and $38 \%$ of those conducting commercial activity employ people from outside the EU (Wieńska-Di Carlo, Klaus 2018, p. 7).

The study has shown that Polish employers still plan to employ nonEU foreigners.

In 2018, $1582 \mathbf{2 2 5}$ declarations on entrusting work to foreigners were issued to non-EU foreigners: 1446304 to citizens of Ukraine, 62 805 to citizens Belarus, 36742 to citizens Moldova; 138334 seasonal work permits were issued: 133372 to citizens of Ukraine, 1860 to citizens of Nepal, 1045 to citizens of Belarus; $\mathbf{3 2 8} 7 \mathbf{6 8}$ work permits for foreigners were issued, including 255616 to citizens of Ukraine, 22315 to citizens of Nepal, 18694 to citizens of Belarus (MRPiPS 2018c; MRPiPS 2018a; MRPiPS 2018b).

According to the data of the Polish Health Insurance Institution, in September 2018, over 569.1 thousand foreigners could apply for pen- 
sion and disability insurance. The number of foreigners from EU countries amounted to 35.6 thousand, and the number of non-EU foreigners - 533.5 thousand, including 425.7 thousand with Ukrainian citizenship. The next largest groups came from non-EU countries, i.e. Belarus 32.6 thousand; Vietnam - 8.1 thousand; Moldova - 7.3 thousand; and Russia 7.3 thousand (ZUS 2019).

"However, the data refers only to foreigners registered for insurance. Unfortunately, due to the common practice of unregistered, illegal work employment of foreigners, it is difficult to estimate their number precisely" (Szpakowska et al., 2017, p. 183).

"The impossibility of assessing the scale of employment of foreigners in Poland is one of the most important limitations of undertaking empirical research on the discussed phenomenon" (Piotrowski, Oraniściak-Krzykowska 2014, p. 268).

The data shows that the largest group of economic migrants in Poland are Ukrainian citizens, who constitute the most active group on the Polish labor market.

The main reasons for the emigration of Ukrainian citizens are the low level of salaries and insufficient employment prospects in Ukraine, frustration caused by the political system, corruption and unstable future. Ukrainians are dissatisfied with the standard and quality of life in Ukraine, young people have limited possibilities after graduating. Wages in Ukraine remain very low and prices continue to rise. In 2018, the average salary in Ukraine amounted to UAH 4173 (USD 148 or PLN 555) while in Poland the average salary at that time amounted to approx. PLN 5000.

The citizens of Ukraine choose Poland mainly because of its territorial proximity and low travel costs. Additionally, extensive migration network is at play: friends, relatives who already work in Poland and provide assistance in departure, or a wide range of intermediaries who help in finding jobs and collect the necessary documents to obtain visas 
or residence permits in Poland. Migrants from Ukraine choose Poland particularly because of the relatively liberal access to the labor market for foreigners with low qualifications or without any qualifications, knowledge of the language or appropriate education. The mass emigration of Ukrainians to Poland was facilitated by the visa-free travel re gime introduced in J une 2016, and Poland is the only EU member state that allows legal employment under the visa-free travel regime. The citizens of Ukrainealso choose Poland because of its cultural and linguistic affinity, which enables them to function in Polish society.

Therefore, themajority of foreigners stayingin Poland comefrom Ukraine.

Analysis of the practical aspects of legalizing foreign labor

The subject literature and the author's several years of experience in working with foreigners show that both employers and foreigners face various problems in obtaining work permits.

In 2018, the Association for Legal Intervention (Stowarzyszenie Interwencji Prawnej) published a report entitled Male and female employers and the issue of employment of male and female foreigners (Wieńska-Di Carlo, Klaus 2018). The report is the result of surveys conducted to examine the needs of entrepreneurs in relation to employment of foreigners and the challenges they face ${ }^{2}$. The research was conducted within the framework of the Migration Laboratory Project (Laboratorium Migracji) $^{3}$. In order to achieve the set goals, the authors used a diverse methodology: CAWI (Computer Assisted Web Interview),

\footnotetext{
${ }^{2}$ The preface comments on the issues addressed by various Polish opinion-making institutions, such as the Konrad Adenauer Foundation, Business Centre Club, the Union of Entrepreneurs and Employers and the Social Dialogue Committee of the Polish Chamber of Commerce. All institutions agree that foreigners contribute immensely to the development of the Polish economy and its rapid growth, and that foreigners' labor is important for the Polish pension system and the future of Polish demography. As a result, the institutions draw attention to a necessary inclusion of a well-thought-out integration policy.

3 Migration Laboratory is a project of the Association for Legal Intervention, established in 2015. Its aim is to provide reliable knowledge on migration and integration of foreigners and to share it with other public or private entities.
} 
which is a quantitative method, and the focus group interview method, which is qualitative.

The choice these particular methodologies allowed for conducting a comprehensivestudy, as the quantitative research facilitated the assessment of the frequency of certain phenomena (employment of foreigners and their characteristics, opinions on employment procedures and attitudes towards foreign workers). The qualitative study allowed to better understand the results of the first stage of the research and to examine the needs and issues of employers with regard to the employment of foreigners.

Quantitative research was conducted on a sample of 303 employers. Purposive sampling was applied according to the enterprise's size (micro, small and medium), its business sector and the location of the company's main office. Surveys were the chosen research tool.

Qualitative research was conducted in three groups of 4-6 people each (representatives of micro, small and medium enterprises).

The report sends an important message, highlighting the growth of issues around the legal provisions concerning non-EU foreigner labor. The authors identified the most important problematic issues related to the employment of foreigners: lack of information, long waiting periods and unclear procedures.

First of all, the lack of information in languages understood by foreigners and insufficient awareness among employers about the legal conditions of employment of foreigners are of prime importance. Employers and foreigners have difficulties understanding the regulations and procedures for obtaining individual permits.

Information about individual permits can be found on official websites, usually only in Polish or in few select foreign languages, and rarely updated. The limited number of helplines and consultation offices makes it impossible for employers and foreigners to obtain additional information, apart from the basic data published on the websites. For 
example, at the headquarters of the Department of Foreigners in Warsaw at 3/5Marszałkowska street, there are no direct information points on the status of pending proceedings, there are automatic helplines, but the telephone hotline has been suspended. Consultations are becoming the responsibility of NGOs, which, due to lack of funding, are not sufficiently numerous and cannot provide assistance to all those in need.

The procedures for obtaining permits are not transparent for employers, who have difficulties understanding which documents are necessary to obtain a permit. Additionally, they often lack information on how to make an appointment, are not aware of their obligations to inform the permit-issuing institution about the decisions concerning the foreigner's permit, the termination of work by the foreigner, the change of conditions, the place of employment etc.

As a result of these unclear procedures, the lack of information and access to free consultation, employers are forced to use intermediaries who obtain work permits for the employees for a certain fee. The services of intermediaries are quite expensive, which is why employers quite often shift expenses onto foreigners. In worse cases, they knowingly or unknowingly employ foreigners illegally.

The most important issue highlighted in the report is the problem of long queues and prolonged periods of case processing. On the website of the Mazowieckie Voivodeship Office, two modes of handling applications for work permits are distinguished: coordinated and uncoordinated. In the coordinated service mode, authorization can be obtained within two months and in the non-coordinated mode - within six months (Mazowiecki Urząd Wojewódzki 2014). However, it is almost impossible to arrange an appointment in the coordinated service mode.

One of the fundamental principles of administrative proceedings, essential and extremely important from the foreigner's perspective, is that a given matter should be processed quickly and efficiently by an institution. 
In practice, however, this ruleis one of the most frequently violated by public administration bodies. Institutions very often fail to meet the deadlines provided for in the Code of Administrative Procedure, and sometimes do not inform the parties about the delay and its reasons and do not set a new deadline for dealing with the case. In addition, when a statutory deadline of 6 months is set for a given case, it is very rare for it to be resolved before the due date. Although a case should be concluded inside the 6-month period, which means that it can be ended earlier, theofficials tend to file their decisions at the very last minute, but the procedure is often delayed further (Wencel 2009).

On 7 August 2019, the Supreme Audit Office published a report on the preparation of public administration in providing services to foreigners, in which it unequivocally stated that, the public administration is not able to cope with the ever-growing number of foreigners migrating to Poland. The period of legalization of their stay almost tripled in duration - from 64 to 206 days. In extreme cases, the foreigner waited more than threeyears for a decision to be issued. There is a lack of efficient, reliable and timely service, which is caused, among other things, by staffing shortages in public institution and insufficient financing of their activities.

Audit of 264 cases concerning the issuance of residence permits, work permits and travel documents to foreigners by voivodes (province governors) showed irregularities in as many as 187 cases (nearly $71 \%$ of the examined cases). The irregularities concerned all the voivodeship offices visited (Najwyższa Izba Kontroli 2019).

Long queues and processing times are frustrating both for foreigners and employers. Employers are often unable to wait for 6 months for the possibility of legal employment of foreigners, and foreigners (especially economic migrants) cannot remain unemployed for 6 months, as they need to support their families and themselves. Therefore, they choose 
to work illegally without a work permit, without paying taxes and insurance contributions. As a result, they very often become victims on the part of employers who do not pay them for the work performed.

In such situations, the mistreated foreigners cannot turn to the National Labor Inspectorate, because a foreigner working illegally is subject to a fine (PLN 1000-5000), and may be required to leave Poland and be banned from re-entering the country within one to three years.

Other noticeable problems consist in formalities related to obtaining information from the Starost (district governor) and issuing work permits allowing to employ a specific person only by a specific employer in a specific position, provided that there is no willing Polish citizen for a such a position. Almost one hundred percent of the labor market examinations are positive, which undermines the need to obtain information from the starost. When changing employers, the foreigner is obliged to obtain a new work permit, which means waiting for new documents for another six months. As a result, foreigners are very often forced to abandon their desire to change jobs.

\section{Summary}

Considering the issues described above, we can conclude that the law concerning the employment of foreigners needs to be amended. For this reason, it is necessary to shorten the duration of the labor and residence legalization processes for foreigners, and introduce simplified and streamlined solutions.

The analysis of the results leads to the conclusion that the existing bureaucratic procedures related to the employment of foreign workers do not have to dissuade employers from legal employment of foreigners, who are necessary for their businesses. This applies not only to employees in senior positions in the company, but also to skilled workers. 
However, the procedure for applying for a work permit and related activities are costly, time-consuming and certainly unpleasant, especially for small enterprises who would like to officially hire a foreigner. It is therefore advisable to streamline this procedure so that small entrepreneurs can deal go through it without intermediaries (Gmaj 2005).

Kinga Wieńska-Di Carlo and Witold Klaus propose to amend the legal provisions in the following way: consider the work of a foreigner as legal from the moment the required documents are submitted by the employer; after 3 years of labor, issue permits for a longer period (for example, 5 years); introduce automated, digitized processes of legalizing foreigners' labor, allowing for the submission of documents online, and after their verification (which would take 2-3 days), an automatic generation of a legalization document; carry out public information campaigns for employers concerning legalizing procedures for non-EU foreigners' labor, in order to promote openness towards hiring foreigners and improve social attitudes towards migrants; provide support to foreigners who have been exploited by Polish employers. In order to achieve the last recommendation, the National Labor Inspectorate should be stripped of its criminal-investigative functions.

On the basis of the study results and the postulated recommendations, an appeal was sent to the Minister of Family, Labor and Social Policy and the Minister of Entrepreneurship and Technology to introduce changes in the law on foreign labor, signed by representatives of em-

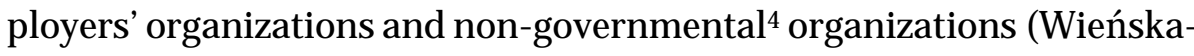
Di Carlo, Klaus 2018).

If, in response to appeals of Polish entrepreneurs, the proposed solutions are introduced, they would allow for more efficient processing

\footnotetext{
4 Business Centre Club, Polish Chamber of Commerce, the Union of Entrepreneurs and Employers Migration Research Centre Foundation, Polish Migration Forum Foundation, Helsinki Foundation for Human Rights, With Bread and Salt Initiative, Institute of Public Affairs, Homo Faber Association, Association for Legal Intervention, Association for Integration of Multicultural Society.
} 
of applications, easier employment of foreigners, lowering the number of intermediaries and the incidence of illegal foreign labor.

References

Gmaj K. (2005), Imigranci na polskim rynku pracy $w$ świetle opinii pracodawców, "Centrum Stosunków Międzynarodowych", nr 3/05, http:// mighealth.net/pl/images/3/34/Imigranci_zarobkowi.pdf [12.08.2019]

Mazowiecki Urząd Wojewódzki (2014), Ile czasu trwa wydanie zezwolenia na pracę?, https:/ / mazowieckie.pl/pl/dla-klienta/ cudzoziemcy/ zezwolenia-na-prace-dl-1/ile-czasu-trwa-wydanie/ 14840,Ile-czasu-trwa-wydanie-zezwolenia-na-prace.html [20.08.2019]

MRPiPS (n.d.), Zatrudnianie cudzoziemców w Polsce, Departament Rynku Pracy, https:// psz.praca.gov.pl/rynek-pracy/statystyki-ianalizy/ zatrudnianie-cudzoziemcow-w-polsce, [7.08.2019]

MPiPS (2009a), Rozporządzenie Ministra Pracy i Polityki Społecznej w sprawie wydania zezwolenia na pracę cudzoziemca, Dz.U. 2009 $\mathrm{nr} 16$, poz. 84

MPiPS (2009b), Rozporządzenia Ministra Pracy i Polityki Społecznej z dn. 29.01.2009r. w sprawie określenia przypadków, w których zezwolenie na pracę cudzoziemca jest wydawane bez względu na szczegółowe warunki wydawania zezwoleń na pracę cudzoziemców, Dz.U. 2009 nr 16 poz. 85

MPiPS (2014), Rozporządzenie Ministra Pracy i Polityki Społecznej w sprawie przypadków, w których powierzenie wykonywania pracy cudzoziemcowi na terytorium Rzeczypospolitej Polskiej jest dopuszczalne bez konieczności uzyskania zezwolenia na pracę, Dz.U. 2015 poz. 588 
MPRPiPS (2018), Rozporządzenie Ministra Rodziny, Pracy i Polityki Społecznej zmieniające rozporządzenie w sprawie podklas działalności według Polskiej Klasyfikacji Działalności (PKD), w których wydawane są zezwolenia na pracę sezonową cudzoziemca, Dz.U. 2018 poz. 1749

MRPiPS (2018a), Zezwolenia na pracę cudzoziemców, Departament Rynku Pracy MRPiPS, http:// psz.praca.gov.pl/ web/ urzad-pracy/ / 8180075-zezwolenia-na-prace-cudzoziemcow [12.08.2019] MRPiPS (2018b), Zezwolenie na pracę sezonowa cudzoziemca, Departament Rynku Pracy MRPiPS, http:// psz.praca.gov.pl// 8180228-zezwolenia-na-prace-sezonowa-cudzoziemca [12.08.2019]

MRPiPS (2018c), Oświadczenia o powierzeniu wykonywania pracy cudzoziemcowi, wpisane do ewidencji oświadczeń (obowiązująe od 2018 r.), Departament Rynku Pracy, https:// psz.praca.gov.pl// 8180211-oswiadczenia-o-powierzeniu-wykonywania-pracy-cudzoziemcowi-wpisane-do-ewidencji-oswiadczen-obowiazujace-od2018-r- [7.08.2019]

Najwyższa Izba Kontroli (2019), Państwo niegotowe na cudzoziemców, https:/ / www.nik.gov.pl/ aktualnosci/ panstwo-niegotowe-nacudzoziemcow.html [20.08.2019]

Oświadczenia o powierzeniu wykonywania pracy cudzoziemcowi, wpisane do ewidencji oświadczeń (obowiązujące od 2018 r.) (2018), Departament Rynku Pracy MRPiPS, http:// psz.praca.gov.pl /-/ 8180211-oswiadczenia-o-powierzeniu-wykonywania-pracy-cudzoziemcowi-wpisane-do-ewidencji-oswiadczen-obowiazujace-od2018-r-, [20.07.2019]

Piekutowska A. (2007), Zatrudnienie cudzoziemców w Polsce a ochrona krajowego rynku pracy, "Białostockie Studia Prawnicze” Vol. 2 
Piotrowski M., Organiściak-Krzykowska A. (2014), Rola cudzoziemców na rynku pracy w Polsce, "Studia Prawno-Ekonomiczne”, tom XCIII

Piotrowski M., Organiściak-Krzykowska A. (2016), Zatrudnienie cudzoziemców na polskim rynku pracy - aspekty popytowe i strukturalne, "Studia Prawno-Ekonomiczne" tom C

Szpakowska J ., Buchwald T., Romanowski R. (2017), Atrakcyjność polskiego rynku pracy dla obywateli Ukrainy - przyczyny, mechanizmy, konsekwencje migracji zarobkowych, "Optimum. Studium Ekonomiczne" nr 5

Urząd do Spraw Cudzoziemców (2019), https:/ / migracje.gov.pl/ statystyki/ zakres/polska/ typ/ dokumenty/ widok/ mapa/rok/ 2019/ ?x=0.2834\&y $=0.6105 \&$ level $=0.5$ [7.08.2019]

Ustawa o cudzoziemcach (2013), Dz.U. 2013 poz. 1650

Ustawa o promocji zatrudnienia i instytucjach rynku pracy (2004), Dz.U. 2018 r. poz. 1265

Wencel K. (2009), Prawa Cudzoziemców $w$ postępowaniu przed organami administracji publicznej, "Analizy, Raporty, Ekspertyzy”, nr 4, https:/ / interwencjaprawna.pl/ docs/ ARE-409-prawacudzoziemca-w-administracji.pdf [12.08.2019]

Wieńska-Di Carlo K., Klaus W. (2018), Pracodawcy i pracodawczynie a zatrudnienie cudzoziemców i cudzoziemek, Stowarzyszenie Interwencji Prawnej, Warszawa

ZUS (2019), Cudzoziemcy w polskim systemie ubezpieczeń społecznych (2019), Departament statystyki i prognoz aktuarialnych Zakładu Ubezpieczeń Społecznych, https:// www.zus.pl/ documents/ 10182/ 2322024/ Cudzoziemcy+w+polskim+systemie+ubezpiecze\%C5\%84+spo\%C5\%82ecznych.pdf/ 4498fca6-981d-a37c3742-8e4e74e20a32 [7.08.2019] 